\title{
Brazilian Atlantic Forest lato sensu: the most ancient Brazilian forest, and a biodiversity hotspot, is highly threatened by climate change
}

\author{
Colombo, AF. and Joly, CA. ${ }^{\mathrm{b} *}$ \\ aPrograma de Pós-graduação em Ecologia, Instituto de Biologia - IB, \\ Universidade Estadual de Campinas - UNICAMP, CP 6109, CEP 13083-970, Campinas, SP, Brazil \\ ${ }^{\text {b} D e p a r t a m e n t o ~ d e ~ B i o l o g i a ~ V e g e t a l, ~ I n s t i t u t o ~ d e ~ B i o l o g i a ~-~ I B, ~}$ \\ Universidade Estadual de Campinas - UNICAMP, CP 6109, CEP 13083-970, Campinas, SP, Brazil \\ *e-mail: cjoly@unicamp.br \\ Received January 8, 2010 - Accepted July 5, 2010 - Distributed October 31, 2010
}

(With 6 figures)

\begin{abstract}
After 500 years of exploitation and destruction, the Brazilian Atlantic Forest has been reduced to less the $8 \%$ of its original cover, and climate change may pose a new threat to the remnants of this biodiversity hotspot. In this study we used modelling techniques to determine present and future geographical distribution of 38 species of trees that are typical of the Brazilian Atlantic Forest (Mata Atlântica), considering two global warming scenarios. The optimistic scenario, based in a $0.5 \%$ increase in the concentration of $\mathrm{CO}_{2}$ in the atmosphere, predicts an increase of up to $2{ }^{\circ} \mathrm{C}$ in the Earth's average temperature; in the pessimistic scenario, based on a $1 \%$ increase in the concentration of $\mathrm{CO}_{2}$ in the atmosphere, temperature increase may reach $4{ }^{\circ} \mathrm{C}$. Using these parameters, the occurrence points of the studied species registered in literature, the Genetic Algorithm for Rule-set Predictions/GARP and Maximum entropy modeling of species geographic distributions/MaxEnt we developed models of present and future possible occurrence of each species, considering Earth's mean temperature by 2050 with the optimistic and the pessimistic scenarios of $\mathrm{CO}_{2}$ emission. The results obtained show an alarming reduction in the area of possible occurrence of the species studied, as well as a shift towards southern areas of Brazil. Using GARP, on average, in the optimistic scenario this reduction is of $25 \%$ while in the pessimistic scenario it reaches $50 \%$, and the species that will suffer the worst reduction in their possible area of occurrence are: Euterpe edulis, Mollinedia schottiana, Virola bicuhyba, Inga sessilis and Vochysia magnifica. Using MaxEnt, on average, in the optimistic scenario the reduction will be of $20 \%$ while in the pessimistic scenario it reaches $30 \%$, and the species that will suffer the worst reduction are: Hyeronima alchorneoides, Schefflera angustissima, Andira fraxinifolia and the species of Myrtaceae studied.
\end{abstract}

Keywords: Brazilian Atlantic Forest trees, climate change, species niche modeling, GARP, MaxEnt.

\section{Mata Atlântica lato sensu: a mais antiga das florestas brasileiras, e um hotspot de biodiversidade, está altamente ameaçada pelas mudanças climáticas}

\begin{abstract}
Resumo
Nos últimos 500 anos de ocupação da costa brasileira, de um total de $1.300 .000 \mathrm{~km}^{2}$, apenas cerca de $8 \%$ da cobertura original da Mata Atlântica foi preservada. Os poucos fragmentos restantes dessa devastação apresentam diversos tamanhos, formas, estádios de sucessão e situação de conservação. Cerca de metade dos remanescentes florestais de grande extensão estão protegidos na forma de Unidades de Conservação. A maioria desses fragmentos se encontra hoje nas regiões serranas, principalmente a fachada da Serra do Mar, por serem impróprias para práticas agrícolas. Neste estudo, usamos técnicas de modelagem para determinar a distribuição geográfica presente e futura de 38 espécies arbóreas típicas da Mata Atlântica lato sensu, considerando dois cenários de aquecimento global. O cenário otimista prevê uma taxa anual de $0,5 \%$ de aumento na concentração de $\mathrm{CO}_{2}$ na atmosfera e um aumento médio da temperatura inferior a $2{ }^{\circ} \mathrm{C}$. O cenário pessimista prevê uma taxa anual de $1,0 \%$ de aumento na concentração de $\mathrm{CO}_{2}$ na atmosfera e um aumento médio da temperatura superior a $3{ }^{\circ} \mathrm{C}$. Usando estes parâmetros, os pontos de ocorrência atual das espécies e o algoritmo genético para previsões baseadas em regras pré-estabelecidas (GARP), desenvolvemos modelos da distribuição futura das espécies estudadas, considerando as temperaturas projetadas para 2050. Os resultados obtidos mostraram uma alarmante redução na área que as espécies estudadas poderão ocupar, bem como um deslocamento da ocorrência atual em direção ao sul do Brasil. Na média, com o cenário otimista, a redução da área potencial de ocorrência é de $25 \%$, enquanto que no cenário pessimista este patamar é da ordem de $50 \%$. As espécies que sofrerão a maior redução na área de ocorrência são: Euterpe edulis, Mollinedia schottiana, Virola bicuhyba, Inga sessilis e Vochysia magnifica.
\end{abstract}

Palavras-chave: Mata Atlântica lato sensu; mudanças climáticas, modelagem de nicho de espécie, GARP, MaxEnt. 


\section{Introduction}

The Brazilian Atlantic Forest sensu lato is classified as an area that comprises three types of forests: Ombrophylus Dense forests, Semideciduous and Deciduous Stationary forests from the South and Southern regions, and Ombrophylus Mist forest, also known as Araucaria forest from Southern Brazil (Joly et al., 1999; Oliveira Filho and Fontes, 2000).

The always green dense forest occurs in an ombrophylus climate without a biologically dry period throughout the year and exceptionally with two months of scarce humidity. The average temperatures are between 22 and $25{ }^{\circ} \mathrm{C}$. Semideciduous and deciduous forests occur in areas with 2 to 5 months of dry season, with the same range of temperatures. On the other hand, the Araucaria forest of Southern Brazil occurs in areas with a subtropical mesotermic climate, with temperature in the range of 12 to $22{ }^{\circ} \mathrm{C}$.

Our current knowledge indicates that this complex biome contains a species diversity higher than most of the Amazon forests. Species richness, the extremely high levels of endemism and the small fraction of the original forest left, led Myers et al. (2000) to rank the Brazilian Atlantic Forest among the top biodiversity hotspots. In the region of Santa Tereza, Espírito Santo State, Thomaz and Monteiro (1997) recorded 443 species of tree per hectare and the tree diversity index can be as high as $\mathrm{H}^{\prime}=4.48$ in the Submontane forests of Serra do Mar State Park in São Paulo State (Rochelle, 2008).

Although there is some controversy about the exact age of the Atlantic Forest, it is regarded as the oldest Brazilian forest (Rizzini, 1997). It is made up of a mixture of species that have evolved from native vegetation from the era in which South America was separating from Africa, 65 million years ago, with the original Ombrophylus dense forest cover. On the other hand, in the northeast and in the south, the Atlantic Forest expanded and retracted during the Quaternary (Brown Jr., 1987; Behling and Negrelle, 2001; Ledru et al., 2005; Bush and Oliveira, 2006). There is also abundant information about possible past connections between the Atlantic Forest and the more recent Forests of the Amazon Basin (Thomas et al., 1998; Costa, 2003)

During the last 500 hundred years, the Atlantic Forest has been exploited and destroyed, being replaced first by sugarcane in the NE region (XVI century), and then later by coffee in Rio de Janeiro and São Paulo (XVIII and XIX century), by cattle ranching in São Paulo and Minas Gerais (XIX and XX century), by cocoa in Bahia (XX century), and more recently by Eucalyptus forest for cellulose and paper production. The forest was also replaced by cities, being the homeland of about 125 million Brazilians, since all state capitals from the S, SE and NE region, including Porto Alegre, Curitiba, São Paulo, Rio de Janeiro, Belo Horizonte, Salvador and Recife, are within the Atlantic Forest domain. Therefore, there is only $7.6 \%$, of the original Atlantic Forest left, and less then $50 \%$ of the remnants are protected in Conservation Units (Fundação SOS Mata Atlântica and INPE, 1998). Including intermediate secondary forests and small fragments ( $<100 \mathrm{ha})$, this percentage increases to $11.4 \%$ (Ribeiro et al., 2009).

Considering the changes in climate forecasted by the International Panel on Climate Change (IPCC, 2007) it is important to consider the consequences of indirect anthropic actions, such as global warming, on the potential distribution of Atlantic Forest trees.

The Genetic Algorithm for Rule-set Prediction/ GARP is one of the tools developed to determine the potential distribution of species, and therefore the possible consequences of changes in temperature, rainfall and humidity (Stockwell and Noble, 1992; Stockwell and Peters, 1999). To establish the model of species distribution, GARP uses points of occurrence of the species studied, relating them with the climatic and topographic characteristics of the place of occurrence. Models generated from this algorithm are described in several publications (Peterson et al., 1999, 2002; Peterson, 2001; Elith et al., 2006). The rules of species distribution generated by GARP may then be projected for altered climatic scenarios of the future (Siqueira and Peterson, 2003) as well as for paleo scenarios (MartinezMeyer et al., 2004).

As in GARP, the Maxent algorithm is another important tool to model species distribution, mainly when data available is only of occurrence, not presence/absence data, since it is based on the principle of maximum entropy (Phillips et al., 2006).

The main objectives of this paper are: to compare projected Atlantic Forest tree species distribution shifts and/or reductions due to global climate change, to similar data produced by Siqueira and Peterson (2003) for Cerrado (another Brazilian biodiversiy hotspot) trees; and, using the same set of data, compare the projections made using GARP with those made using Maxent.

\section{Material and Methods}

\subsection{Area of study}

We have used the area established by IBGE (1988) as Atlantic Forest, which comprises the following types of vegetation: Ombrophylus Dense and Mixed Ombrophylus (Araucaria forest) Forests, Seasonal Semideciduous and Deciduous Forests, Coastal Plain Restingas, Mangroves and Dunes as well as high altitude rocky outcrop vegetation (Figure 1). This concept of Atlantic Forest, as proposed by Joly et al. (1999) and Oliveira Filho and Fontes (2000) has been recently recognised by the Brazilian National Congress through Law number 11.428 from December 2006.

\subsection{List of species, data on distributions and ecological dimensions}

Based on the work of Oliveira (2001) and Scudeller and Martins (2003), who compared more the 100 lists of arboreal species from phytossociologic studies carried out within the Atlantic Forest Biome, we selected 38 species for which there was sufficient data on its current distribution, and categorised them with early secondary and late secondary, based on Rodrigues et al. (2007) (Table 1). As in Siqueira 


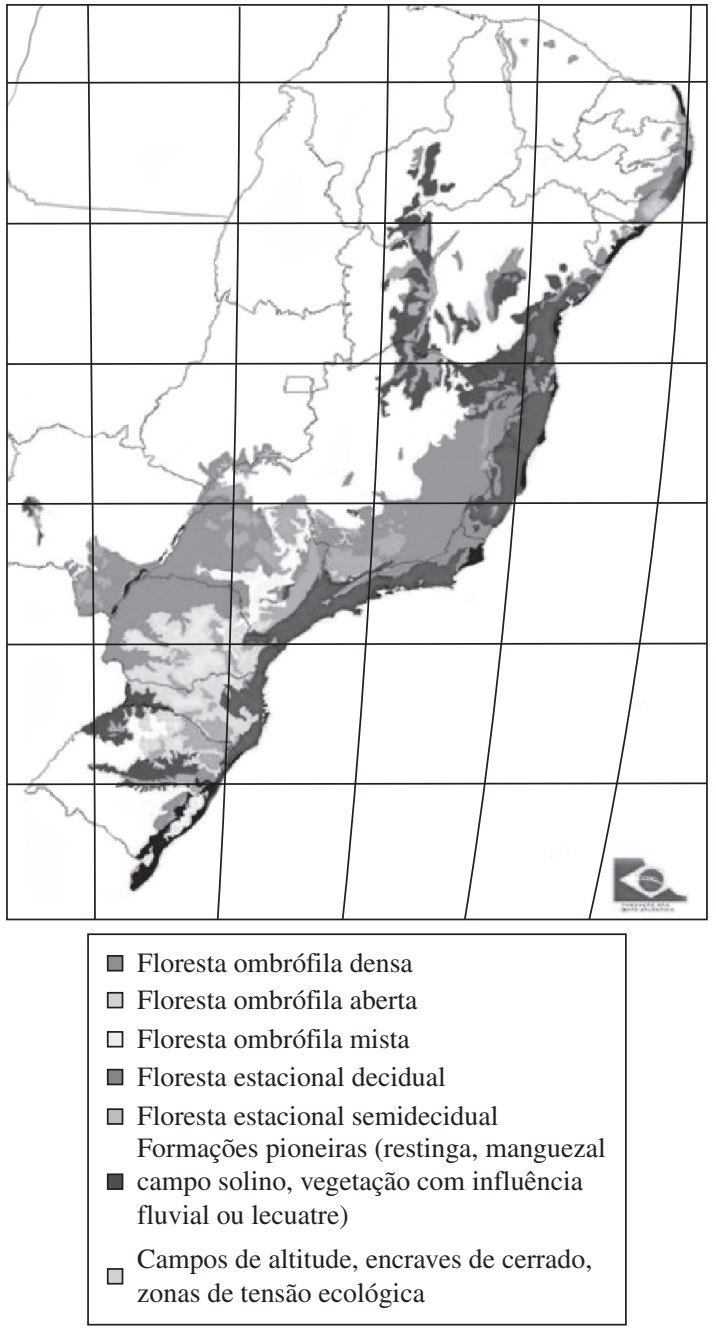

Figure 1. Phytophysiognomies of the Atlantic Forest lato sensu (IBGE, 1993).

and Peterson (2003) a limitation of this study is that only those species for which $>30$ unique occurrence records were available were used. Hence, we considered only those species with relatively broad geographic distribution.

Distributional data representing 2,837 records (i.e., unique species $\times$ latitude-longitude combinations) for these 38 species were assembled from the databanks of the BIOTA/FAPESP Program (SinBiota, 2006) and the FITOGEO databank (Scudeller and Martins, 2003). These data were selected and transformed into decimal degrees, and adjusted to DATUN WGS84 (Figure 2). Duplicated data and those with errors of coordinates were excluded.

\subsection{Environmental variables}

Aiming to produce data comparable to that of Siqueira and Peterson (2003), environmental data included 9 electronic map layers summarising slope, aspect, and upward curvature "topoind" (from the U.S. Geological Survey's (http://edc. usgs.gov/products/elevation/gtopo30/hydro/index.html Hydro-1K data set), and aspects of climate including diurnal temperature range; mean annual precipitation; maximum, minimum, and mean annual temperatures; and vapor pressure (annual means 1960-1990) from the Intergovernmental Panel on Climate Change (http://www. ipcc.ch/), exactly the same used by Siqueira and Peterson (2003) to project possible climate change consequences for Cerrado trees.

\subsection{Scenarios of climate change}

The scenario models used are described in detail in Siqueira and Peterson, (2003) and are similar to scenarios $\mathrm{B} 1$ and A1F1 from the latest report of the International Panel on Climate Change (IPCC, 2007). The optimistic scenario forecasts an increase of $0.5 \%$ per year in the concentration of $\mathrm{CO}_{2}$ in the atmosphere, projects an average increase in mean temperature $\leq 2{ }^{\circ} \mathrm{C}$, while the pessimistic scenario forecasts an increase of $1 \% / \mathrm{yr} \mathrm{CO}_{2}$ and projects a mean temperature increase $\geq 4{ }^{\circ} \mathrm{C}$.

With regard to the projection of future scenarios, we used the projection layers from climate changes for the next 50 years and the same data for topographic aspects, taking into account the little probability of topographic change for the next 50 years. These projections from climate layers have a resolution of $50 \times 50 \mathrm{~km}$, showing, therefore, a low accuracy as they generalise the climatic data. This difference in scale, $50 \times 50 \mathrm{~km}$ of the climate layers, and $1 \times 1 \mathrm{~km}$ of topographic layers, produces loss of quality and interferes with the definition of the potential distribution of the species. Aiming at the minimisation of such difficulty, all maps were rebuilt for a resolution of $5 \times 5 \mathrm{~km}$ (Chapman et al., 2005) cut for the Brazilian territory, making the process of development of models more efficient, rapid, and minimising the loss of data of the more detailed models $(1 \times 1 \mathrm{~km})$.

\subsection{Ecological niche and genetic algorithm (GARP)}

In order to produce data comparable to Cerrado trees, we used the Genetic Algorithm for Rule-set Prediction (GARP) as Siqueira and Peterson (2003) did in their study. Using the software DesktopGarp 1.1.4, freely available at (http://www.lifemapper.org/desktopgarp/), 114 models of distributions were generated, being 38 models for the current distribution of each species, and 76 projections for future scenarios (38 projections using the pessimistic scenario and 38 for the optimistic scenario). For each species, the minimum of points considered was 30 , being $1 / 3$ of them previously separated randomly for the external validation of the models, and the other $2 / 3$ were effectively used to establish the model of distribution of each species. Each distribution model is the result of 100 runs, to reach a coefficient of conversion of 0.01 and a maximum of interactions of 1,000 per species, using four rules: anatomy, range, denied range, and logistic regression.

It is important to stress that GARP works only with points of occurrence and thus the software selects internally 
points of pseudo-absence in the development of its models and also uses only a percentage of the total points for the effective establishment of the models, using the rest for test intrinsic to the program (Siqueira and Peterson, 2003). In this work, we used the tool denominated Best subset, which selects the 10 highest models in relation to the maximum amount of points of intrinsic tests contained in the resultant models. There were randomly selected $50 \%$ of points for the internal, intrinsic validation with a minimum of 20 points for creating the models, therefore, with an omission rate of $10 \%$ and a commission rate of $50 \%$.

After the creation and identification of the 10 best models for each species and each scenario (present, optimistic future and pessimistic future), these were summed through the software ArcView $8^{\circledR}$, resulting in a unique model of distribution for each species and scenario. In every model, we have calculated the size of the area of distribution from the amount of cells of each model (transforming them in area $-\mathrm{km}^{2}$ ) for comparing it with the other models of each one of the 38 species studied.

The statistical analyses were carried out using the software BIOSTAT 2, matching the set of intrinsic data (1/3 of the points that were not used in the creation of the models) with the area of likely occurrence of the present species, therefore, performing a binomial test of two proportions to verify whether the present distribution obtained is different from a distribution with random points.

\subsection{Maximum entropy modelling of species geographic distributions/MaxEnt}

To compare data generated by GARP with those using Maxent, we used the same set of present occurrence data, as well as the same size of cells and the same climate change projections. Maxent models were generated using the following standards: Convergence Threshold: 0.00001; Maximum Iterations: 500; Auto-features: yes; Regularisation multiplier: 1.

The GRID projections generated by MaxEnt were exported to ArcView 9 and re-sampled in a 1-100 scale. Thereafter we used the same specifications used for the GARP projections, so that it was possible to compare results without further transformation and/or analysis.

\section{Results}

All GARP and Maxent projection models of the present area of occurrence of the 38 species presented a high level of significance (Binomial Test: two proportions, $\mathrm{p}<0.05$ for all species); showing that the models based only on

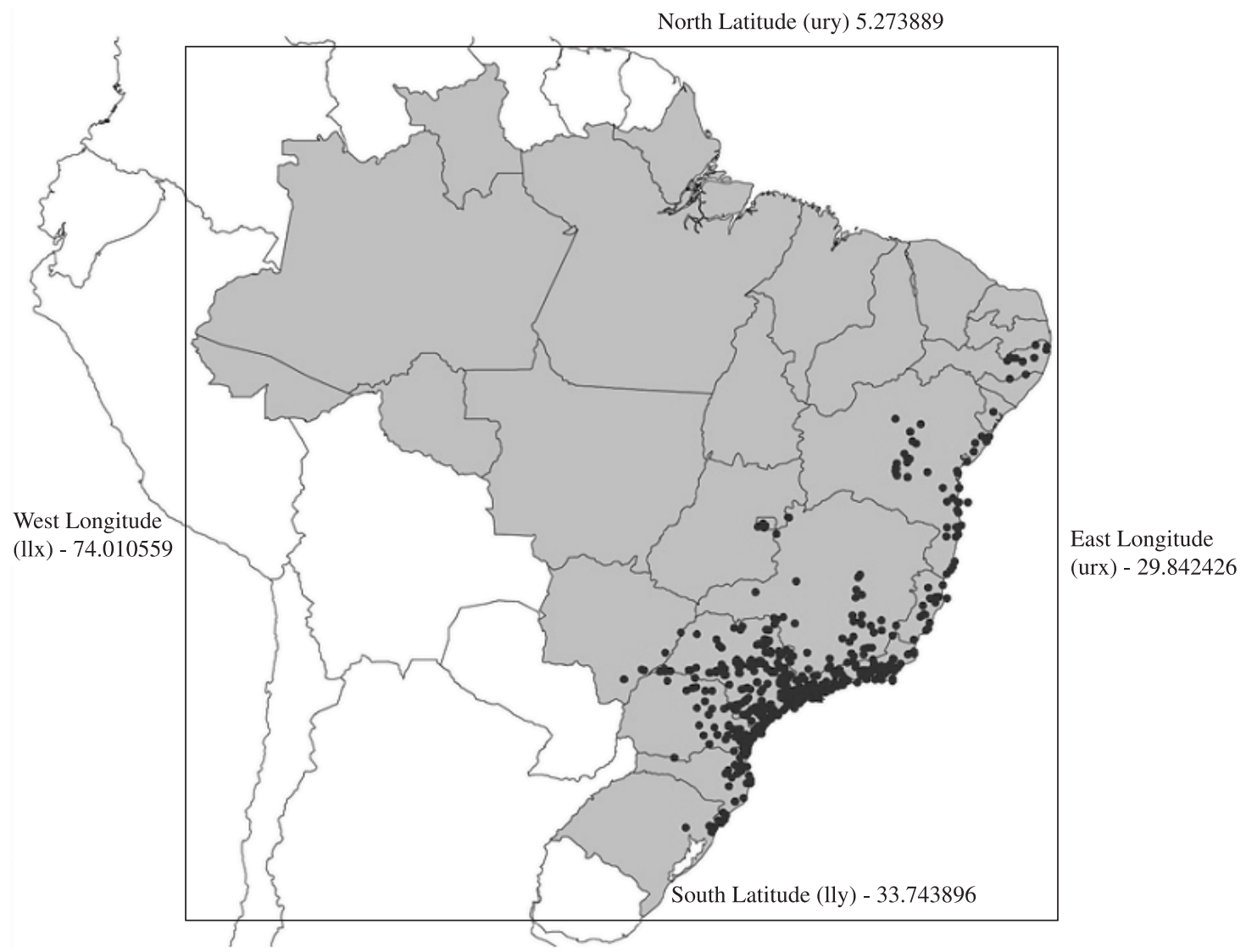

Figure 2. Present occurrence points of the 38 species studied. 
Table 1. List of the 38 arboreal species from the Atlantic Forest Biome used for the development of the models of present and future geographic distribution. Class = classification in functional groups: $\mathrm{E}=$ early secondary; $\mathrm{L}=$ late secondary, based on Rodrigues et al. (2007).

\begin{tabular}{|c|c|c|}
\hline Family & Species & Class. \\
\hline \multirow[t]{2}{*}{ Annonaceae } & Guatteria australis A.St.Hil. & $\mathrm{E}$ \\
\hline & Rollinia sericea (R.E.Fries) R.E.Fries & $\mathrm{L}$ \\
\hline Apocynaceae & Malouetia arborea (Vell.) Miers & $\mathrm{L}$ \\
\hline \multirow[t]{2}{*}{ Araliaceae } & Schefflera angustissima (Marchal) Frodin & $\mathrm{E}$ \\
\hline & Schefflera calva (Cham.) Frodin \& Fiaschi & $\mathrm{E}$ \\
\hline Arecaceae & Euterpe edulis Mart. & $\mathrm{E}$ \\
\hline Bignoniaceae & Jacaranda puberula Cham. & $\mathrm{E}$ \\
\hline Celastraceae & Maytenus robusta Reissek & $\mathrm{L}$ \\
\hline Chrysobalanaceae & Hirtella hebeclada Moric. ex DC. & $\mathrm{L}$ \\
\hline Clethraceae & Clethra scabra Pers. & $\mathrm{E}$ \\
\hline Clusiaceae & Garcinia gardneriana (Planch. \& Triana) Zappi & $\mathrm{L}$ \\
\hline Elaeocarpaceae & Sloanea guianensis (Aubl.) Benth. & $\mathrm{L}$ \\
\hline \multirow[t]{2}{*}{ Euphorbiaceae } & Alchornea triplinervia (Spreng.) Müll.Arg. & $\mathrm{E}$ \\
\hline & Pera glabrata (Schott) Poepp. ex Baill. & $\mathrm{E}$ \\
\hline \multirow[t]{3}{*}{ Lauraceae } & Aniba firmula (Nees \& Mart.) Mez & $\mathrm{L}$ \\
\hline & Nectandra oppositifolia Nees & $\mathrm{E}$ \\
\hline & Ocotea dispersa (Nees) Mez & $\mathrm{L}$ \\
\hline Leg. Caesalpinioideae & Sclerolobium denudatum Vogel & $\mathrm{E}$ \\
\hline Leg. Mimosoideae & Inga sessilis (Vell.) Mart. & $\mathrm{E}$ \\
\hline Leg. Papilionoideae & Andira fraxinifolia Benth. & $\mathrm{E}$ \\
\hline Meliaceae & Guarea macrophylla Vahl & $\mathrm{L}$ \\
\hline Monimiaceae & Mollinedia schottiana (Spreng.) Perkins & $\mathrm{L}$ \\
\hline Myristicaceae & Virola bicuhyba (Schott.) Warb. & $\mathrm{E}$ \\
\hline \multirow[t]{6}{*}{ Myrtaceae } & Calyptranthes grandifolia O.Berg & $\mathrm{L}$ \\
\hline & Eugenia cerasiflora Miq. & $\mathrm{L}$ \\
\hline & Eugenia oblongata O.Berg & $\mathrm{L}$ \\
\hline & Marlierea obscura O.Berg & $\mathrm{L}$ \\
\hline & Marlierea tomentosa Cambess. & $\mathrm{L}$ \\
\hline & Myrcia pubipetala Miq. & $\mathrm{L}$ \\
\hline Myrsinaceae & Myrsine coriacea (Sw.) R. Br. ex Roem. \& Schult. & $\mathrm{E}$ \\
\hline Nyctaginaceae & Guapira opposita (Vell.) Reitz & $\mathrm{E}$ \\
\hline Olacaceae & Heisteria silvianii Schwacke & $\mathrm{L}$ \\
\hline Phyllanthaceae & Hyeronima alchorneoides Allemao & $\mathrm{E}$ \\
\hline Rubiaceae & Amaioua guianensis Aubl. & $\mathrm{L}$ \\
\hline Sapindaceae & Cupania oblongifolia Mart. & $\mathrm{E}$ \\
\hline \multirow[t]{2}{*}{ Sapotaceae } & Chrysophyllum flexuosum Mart. & $\mathrm{E}$ \\
\hline & Ecclinusa ramiflora Mart. & $\mathrm{L}$ \\
\hline Vochysiaceae & Vochysia magnifica Warm. & $\mathrm{L}$ \\
\hline
\end{tabular}

climatic and topographic variables could not present such distribution only by chance (Figure 3 ). As expected, the area projected by MaxEnt, a deterministic tool, is smaller than that projected by GARP, a probabilistic tool (Peterson et al., 2007).

\subsection{Using GARP}

The species studied can be divided in two major groups, if we consider the more optimistic scenario of climate change: one group, of 6 species, that will be marginally affected by an increase in up to $2{ }^{\circ} \mathrm{C}$ in mean average temperatures, i.e., the change in the potential distribution will be near the error margins of the methods used $( \pm 10 \%$ ) (Figure $4 a, b)$; a second group of 32 species that will effectively have a significant reduction in their distribution areas, from which 2 will lose more than $50 \%$ of its occurrence area. If we consider the pessimistic scenario, $50 \%$ of the 38 species studied will have reductions of more than $50 \%$.

Climate change will affect species with very restricted present occurrence area, such as Vochysia magnifica as 

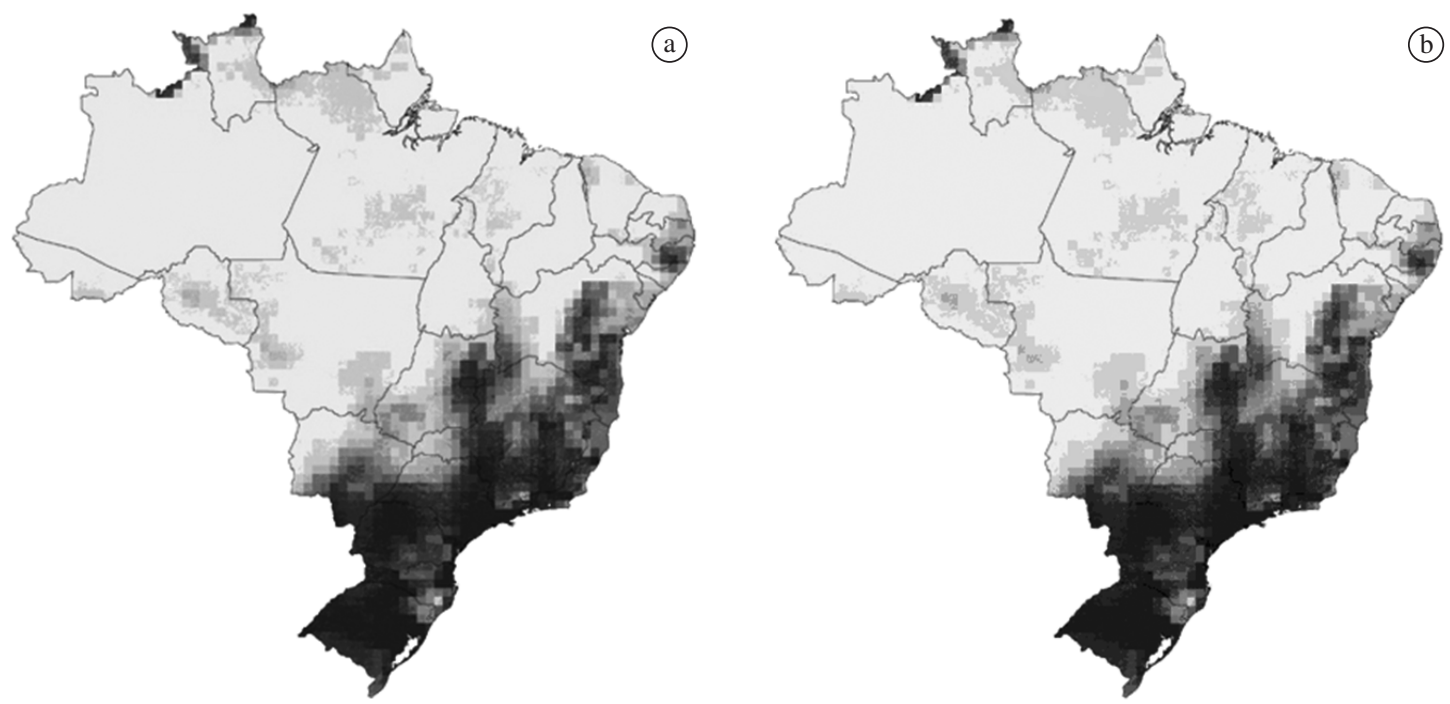

Figure 3. Map of the present occurrence a) using GARP; and b) using MaxEnt.
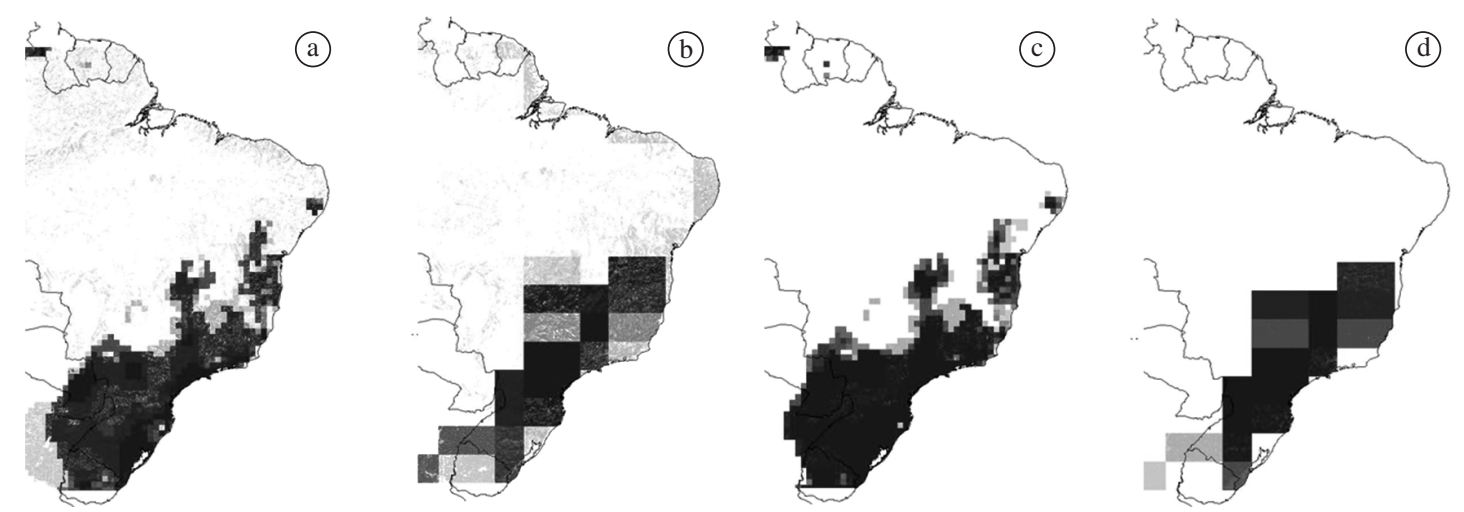

Figure 4. Calyptranthes grandifolia O.Berg. (Myrtaceae): a) Present occurrence; and b) occurrence projected if temperature increases $\leq 2{ }^{\circ} \mathrm{C}$. Euterpe edulis Mart. (Arecaceae): c) Present occurrence; and d) occurrence projected if temperature increases $\leq 2{ }^{\circ} \mathrm{C}$. Both using GARP.
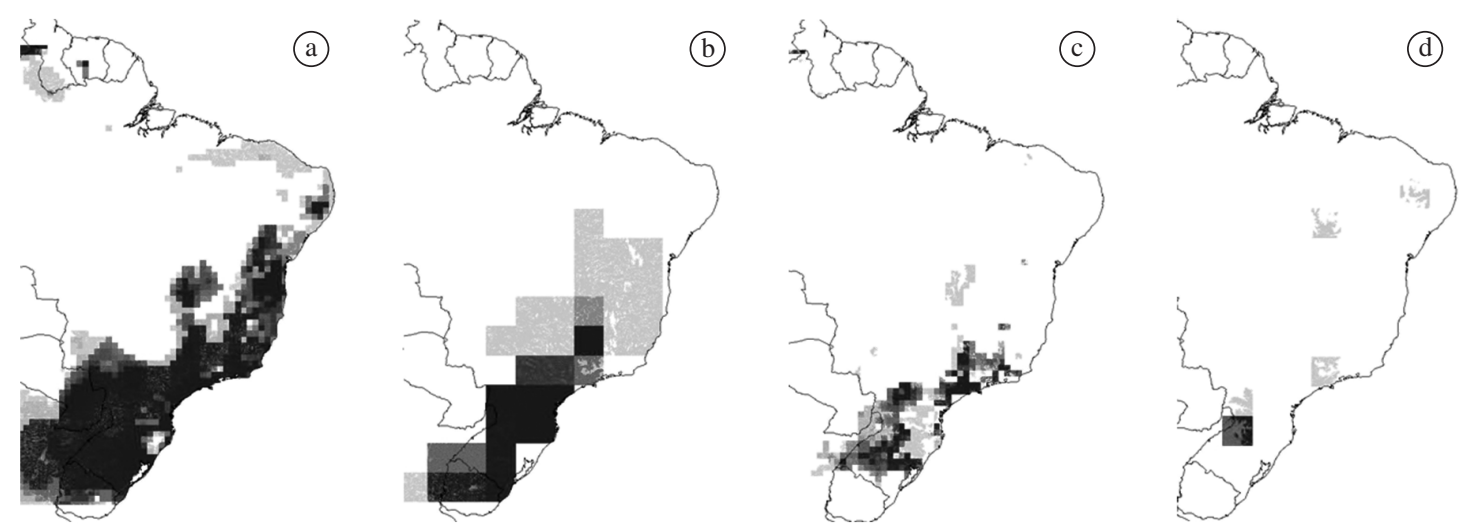

Figure 5. Cupania oblongifolia Mart. (Sapindaceae): a) Present occurrence; and b) occurrence projected if temperature increases $\geq 3{ }^{\circ} \mathrm{C}$. Vochysia magnifica Warm. (Vochysiaceae) c) Present occurrence; and d) occurrence projected if temperature increases $\geq 3{ }^{\circ} \mathrm{C}$. Both using GARP. 
well as those occupying today a wide range of conditions and latitudes within the Atlantic Forest biome, such as Ecclinusa ramiflora (Figure 5a, b).

Another striking result is that only one species, $2.5 \%$ of our sample, will increase its potential occurrence area, but only if the temperatures increase by up to $2{ }^{\circ} \mathrm{C}$. Chrysophyllum flexuosum is very common in a wide range of areas covered by the Atlantic Forest (Oliveira Filho and Fontes, 2000), but does not have any known special feature which explains why it could benefit from a warmer climate.
Some species like Marlierea tomentosa and Rollinia sericea presented less then $10 \%$ of reduction in their occurrence area, if we consider the optimistic scenario (Table 2). While for Marlierea obscura, Ocotea dispersa, Mollinedia schottiana, Schefflera angustissima, Eugenia oblongata and Myrcia pubipetala the expected reduction is below 20\% (Table 2). On the other hand, for species like Vochysia magnifica and Ecclinusa ramiflora this small increase in average temperatures $\left(\leq 2{ }^{\circ} \mathrm{C}\right)$ is sufficient to reduce dramatically, by more than $50 \%$, their occurrence area (Table 2).

Table 2. Data on present occurrence area in square kilometres, projection of occurrence areas with the optimistic and pessimistic scenarios, using GARP.

\begin{tabular}{|c|c|c|c|c|c|c|}
\hline Family & Species & $\begin{array}{c}\text { Present } \\
\left(\mathbf{k m}^{2}\right)\end{array}$ & $\begin{array}{c}\text { Optimistic } \\
\left(\mathbf{k m}^{2}\right)\end{array}$ & $\begin{array}{c}\% \\
\text { reduction }\end{array}$ & $\begin{array}{c}\text { Pessimistic } \\
\left(\mathbf{k m}^{2}\right)\end{array}$ & $\begin{array}{c}\% \\
\text { reduction }\end{array}$ \\
\hline \multirow[t]{2}{*}{ Annonaceae } & Guatteria australis & $3,726,625$ & $2,972,125$ & 20,25 & $2,219,450$ & 40,44 \\
\hline & Rollinia sericea & 964,650 & 904,550 & 6,23 & 615,825 & 36,16 \\
\hline \multirow[t]{2}{*}{ Apocynaceae } & Malouetia arborea & $2,609,550$ & $2,044,450$ & 21,66 & $1,206,275$ & 53,77 \\
\hline & Schefflera angustissima & $2,660,625$ & $2,182,400$ & 17,97 & $1,141,275$ & 57,11 \\
\hline Araliaceae & Schefflera calva & $2,329,500$ & $1,485,575$ & 36,23 & $1,020,375$ & 56,2 \\
\hline Arecaceae & Euterpe edulis & $2,320,325$ & $1,941,250$ & 16,34 & 947,050 & 59,18 \\
\hline Bignoniaceae & Jacaranda puberula & $3,829,000$ & $2,665,125$ & 30,4 & $1,555,050$ & 59,39 \\
\hline Celastraceae & Maytenus robusta & $3,078,350$ & $2,447,600$ & 20,49 & $1,894,325$ & 38,46 \\
\hline Chrysobalanaceae & Hirtella hebeclada & $3,157,100$ & $2,483,200$ & 21,35 & $1,676,650$ & 46,89 \\
\hline Clethraceae & Clethra scabra & $3,071,600$ & $2,320,150$ & 24,46 & $1,292,225$ & 57,93 \\
\hline Clusiaceae & Garcinia gardneriana & $7,699,375$ & $4,214,750$ & 45,26 & $3,294,050$ & 57,22 \\
\hline \multirow[t]{2}{*}{ Elaeocarpaceae } & Sloanea guianensis & $7,300,750$ & $4,166,225$ & 42,93 & $3,160,300$ & 56,71 \\
\hline & Alchornea triplinervia & $4,368,275$ & $3,161,925$ & 27,62 & $2,463,150$ & 43,61 \\
\hline \multirow[t]{3}{*}{ Euphorbiaceae } & Pera glabrata & $4,924,125$ & $3,142,925$ & 36,17 & $2,542,675$ & 48,36 \\
\hline & Aniba firmula & $8,819,200$ & $5,038,525$ & 42,87 & $3,884,675$ & 55,95 \\
\hline & Nectandra oppositifolia & $3,246,250$ & $2,394,100$ & 26,25 & $1,399,625$ & 56,88 \\
\hline Lauraceae & Ocotea dispersa & $1,418,025$ & $1,256,900$ & 11,36 & 655,600 & 53,77 \\
\hline Leg. Caesal. & Sclerolobium denudatum & $3,369,275$ & $2,439,125$ & 27,61 & $2,081,875$ & 38,21 \\
\hline Leg. Mimo. & Inga sessilis. & $2,743,475$ & $2,063,475$ & 24,79 & $1,011,325$ & 63,14 \\
\hline Leg. Papil. & Andira fraxinifolia & $6,420,575$ & $4,334,850$ & 32,49 & $3,160,000$ & 50,78 \\
\hline Meliaceae & Guarea macrophylla & $8,922,075$ & $5,059,625$ & 43,29 & $4,974,625$ & 44,24 \\
\hline Monimiaceae & Mollinedia schottiana & $2,544,250$ & $2,225,250$ & 12,54 & $1,020,825$ & 59,88 \\
\hline Myristicaceae & Virola bicuhyba & $2,031,175$ & $1,419,300$ & 30,12 & 783,125 & 61,44 \\
\hline \multirow[t]{6}{*}{ Myrsinaceae } & Myrsine coriacea & $6,282,525$ & 3469900 & 44,77 & 2800375 & 55,43 \\
\hline & Calyptranthes grandifolia & $3,600,725$ & $3,429,375$ & 4,76 & $2,540,350$ & 29,45 \\
\hline & Eugenia cerasiflora & $3,466,475$ & $2,742,675$ & 20,88 & $1,692,175$ & 51,18 \\
\hline & Eugenia oblongata & $2,859,125$ & $2,341,525$ & 18,1 & $1,545,875$ & 45,93 \\
\hline & Marlierea obscura & $3,439,100$ & $3,075,525$ & 10,57 & $2,100,775$ & 38,91 \\
\hline & Marlierea tomentosa & $3,474,925$ & $3,319,650$ & 4,47 & $2,133,700$ & 38,6 \\
\hline Myrtaceae & Myrcia pubipetala & $3,746,900$ & $3,015,525$ & 19,52 & $2,305,525$ & 38,47 \\
\hline Nyctaginaceae & Guapira opposita & $4,299,800$ & $2,794,675$ & 35 & $2,271,725$ & 47,17 \\
\hline Olacaceae & Heisteria silvianii & $1,220,400$ & 902,400 & 26,06 & 657,300 & 46,14 \\
\hline Phyllanthaceae & Hyeronima alchorneoides & $4,406,225$ & $2,969,125$ & 32,62 & $2,413,475$ & 45,23 \\
\hline Rubiaceae & Amaioua guianensis & $9,412,800$ & $5,718,575$ & 39,25 & $5,010,000$ & 46,77 \\
\hline \multirow[t]{2}{*}{ Sapindaceae } & Cupania oblongifolia & $3,522,900$ & $3,464,300$ & 1,66 & $2,307,250$ & 34,51 \\
\hline & Chrysophyllum flexuosum & $3,261,350$ & $3,552,800$ & $-8,94$ & $2,245,125$ & 31,16 \\
\hline Sapotaceae & Ecclinusa ramiflorat. & $8,824,675$ & $3,997,675$ & 54,7 & $2,888,625$ & 67,27 \\
\hline Vochysiaceae & Vochysia magnifica & 734,500 & 353,475 & 51,88 & 199,350 & 72,86 \\
\hline
\end{tabular}



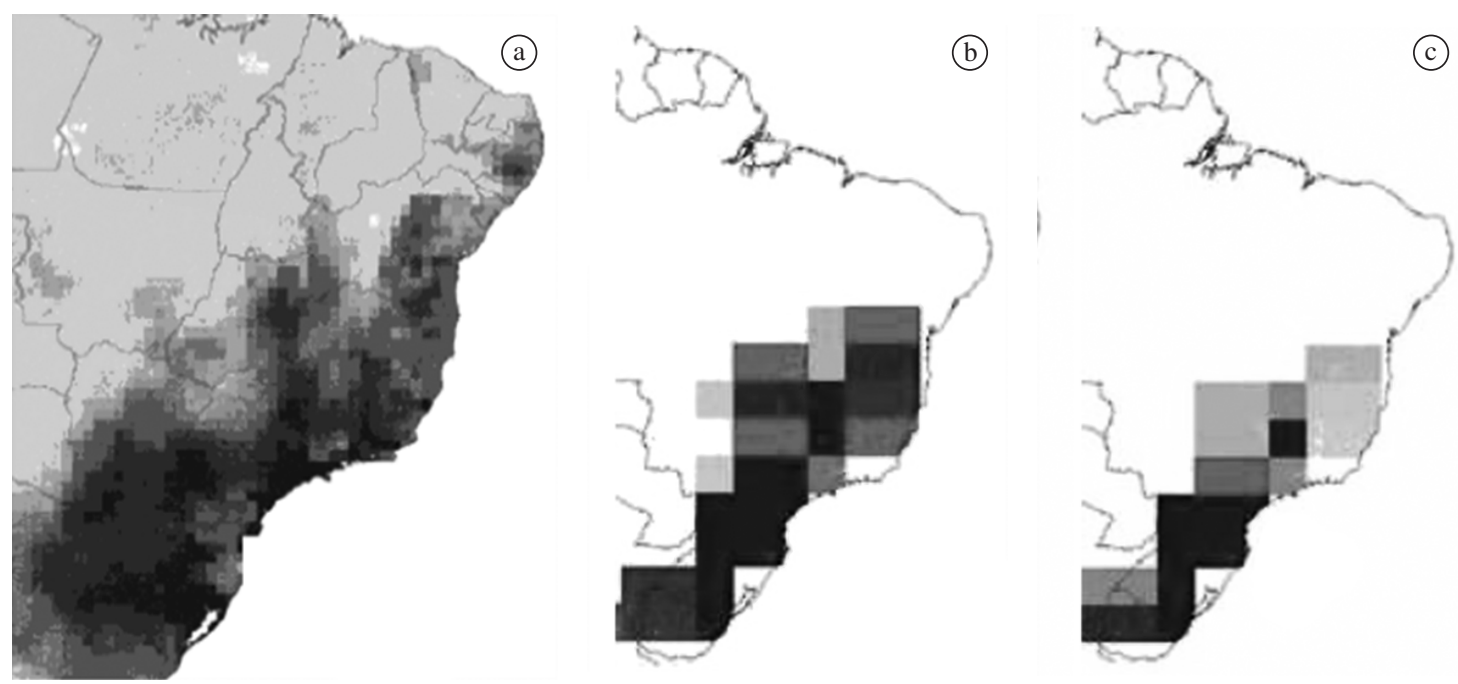

Figure 6. Map of the sum of the areas of potential occurrence of the 38 species studied in both scenarios. a) present occurrence of species; b) occurrence of species in the optimistic scenario; and c) occurrence of species in the pessimistic scenario, using GARP.

Considering the pessimistic scenario, in which the increase in average temperatures will be $\geq 3{ }^{\circ} \mathrm{C}$, all species studied will have their occurrence area significantly reduced. For species like Calyptranthes grandifolia, Chrysophyllum flexuosum, Cupania oblongifolia, Rollinia sericea, Sclerolobium denudatum, Maytenus robusta, Myrcia pubipetala, Marlierea tomentosa and Marlierea obscura this reduction will stay between 30 and $40 \%$ of the present occurrence area (Table 2). While for Virola bicuhyba, Inga sessilis Ecclinusa ramiflora and Vochysia magnifica this reduction will reach more then $60 \%$ (Table 2).

After analysing individually each species, the projected reductions were all summed to present a general panorama of the consequences of global warming for the most endangered Brazilian forest (Figure 6). The general result shows not only a significant reduction in the potential distribution of the species studied but also that the Atlantic Forest may be restricted to a more southern position in Brazil.

\subsection{Using MaxEnt}

Projection models produced using MaxEnt can be divided into three groups (Table 3): species that showed exactly the same behaviour observed in GARP models (30); species that showed an increase in the potential area of occurrence with the optimistic scenario (4); species that presented an increase in the potential area of occurrence in both scenarios (4). These last two groups may indicate that some species of the Atlantic Forest are not occupying their optimal area of occurrence today, which can be due to competition or to the present distribution of pollinators or dispersers.

For the 30 species that presented a significant reduction in their potential area of occurrence, global warming has a strong negative impact and displacement towards higher latitudes (South in the case of Brazil) is a strong tendency. The same pattern was observed using GARP.
The four species that presented an increase in their occurrence area, in both the optimistic and pessimistic scenarios, have high phenotypic plasticity and are benefitted by a more homogeneous environment imposed by higher temperatures, or are not occurring in its best conditions today.

\section{Discussion}

Using GARP, the average reduction of occurrence areas found for these 38 species of trees from the Atlantic Forest is lower than that reported by Siqueira and Peterson (2003) for Brazilian Cerrado species. Using the same climatic scenarios that we have used, they reported that 91 , from the 162 tree species studied, should have more than $90 \%$ of reduction in its occurrence if mean temperatures increase by up to $2{ }^{\circ} \mathrm{C}$. This number increases to 123 when the pessimistic scenario is used. More significant than this high percentage of reduction is the fact that 18 species in the optimistic scenario, and 56 in the pessimistic scenario, tend to extinction, since the predicted potential area of occurrence is null (Siqueira and Peterson, 2003).

Using MaxEnt the average reduction of occurrence area is lower both for early secondary species, $22.01 \%$ in the optimistic scenario and $28.32 \%$ in the pessimistic scenario, and late secondary species, 18.34 and $29.47 \%$, respectively. Nevertheless the pattern of the tendency, reduction in the area of occurrence and shift towards more southern areas of Brazil, are the same.

If we consider the sum of the maps of today's occurrence of the Atlantic Forest species studied, there are several areas where there is a high probability ( $>80 \%$ ) of a concomitant occurrence of those 38 species. For instance: the Northern part of Rio Grande do Sul State; the extreme West and the coastal area of Santa Catarina State; the Centre and North-western parts of Paraná State; the entire coast of 
Table 3. Data on present occurrence area in square kilometres, projection of occurrence areas with the optimistic and pessimistic scenarios using MaxEnt.

\begin{tabular}{|c|c|c|c|c|c|c|}
\hline Family & Species & $\begin{array}{c}\text { Present area } \\
\left(\mathbf{k m}^{2}\right)\end{array}$ & $\begin{array}{l}\text { Optimistic } \\
\text { area }\left(\mathbf{k m}^{2}\right)\end{array}$ & $\begin{array}{c}\% \\
\text { reduction }\end{array}$ & $\begin{array}{l}\text { Pessimistic } \\
\text { area }\left(\mathbf{k m}^{2}\right)\end{array}$ & $\begin{array}{c}\% \\
\text { reduction }\end{array}$ \\
\hline \multirow[t]{2}{*}{ Annonaceae } & Guatteria australis & 571,990 & 488,915 & 4,5239 & 418,770 & 26,7872 \\
\hline & Rollinia sericea & 495,790 & 378,810 & 23,5947 & 285,335 & 42,4484 \\
\hline Apocynaceae & Malouetia arborea & 885,770 & 509,705 & 42,4563 & 424,425 & $-52,081$ \\
\hline \multirow[t]{2}{*}{ Araliaceae } & Schefflera angustissima & 763,990 & 417,445 & 45,3599 & 264,070 & 65,4354 \\
\hline & Schefflera calva & $1,490,720$ & $1,436,150$ & 3,6607 & $1,523,930$ & 2,2278 \\
\hline Arecaceae & Euterpe edulis & 468,275 & 407,885 & 12,8963 & 342,270 & 26,9083 \\
\hline Bignoniaceae & Jacaranda puberula & 581,725 & 416,065 & 28,4774 & 347,535 & 40,2579 \\
\hline Celastraceae & Maytenus robusta & 617,555 & 417,620 & 32,3753 & 329,960 & 46,5699 \\
\hline Chrysobalanaceae & Hirtella hebeclada & 573,030 & 425,560 & 25,735 & 357,640 & 37,587 \\
\hline Clethraceae & Clethra scabra & 463,050 & 421,970 & 8,8716 & 406,680 & 12,1736 \\
\hline Clusiaceae & Garcinia gardneriana & $1,295,700$ & $1,417,395$ & $-9,39222$ & $1,533,745$ & $-18,3719$ \\
\hline Elaeocarpaceae & Sloanea guianensis & $1,410,395$ & 849,610 & 39,7608 & 897,600 & 36,3583 \\
\hline \multirow[t]{2}{*}{ Euphorbiaceae } & Alchornea triplinervia & 697,380 & 569,170 & 18,3845 & 624,625 & 10,4326 \\
\hline & Pera glabrata & $1,117,885$ & 716,500 & 35,9058 & 656,930 & 41,2346 \\
\hline \multirow[t]{3}{*}{ Lauraceae } & Aniba firmula & $1,205,355$ & $1,055,925$ & 12,3972 & $1,193,630$ & 0,9727 \\
\hline & Nectandra oppositifolia & 443,725 & 414,135 & 6,6685 & 370,005 & 16,6139 \\
\hline & Ocotea dispersa & 245,120 & 295,260 & $-20,4553$ & 169,850 & 30,7074 \\
\hline Leg. Caesal. & Sclerolobium denudatum & 743,415 & 512,805 & 31,0204 & 457,575 & 38,4496 \\
\hline Leg. Mimo. & Inga sessilis. & 350,205 & 412,865 & $-17,8924$ & 363,910 & $-3,9134$ \\
\hline Leg. Papil. & Andira fraxinifolia & $1,161,410$ & 500,915 & 56,8701 & 435,180 & 62,5300 \\
\hline Meliaceae & Guarea macrophylla & $1,626,275$ & $1,114,290$ & 31,4821 & $1,246,045$ & 23,3804 \\
\hline Monimiaceae & Mollinedia schottiana & 295,325 & 409,560 & $-38,6811$ & 300,865 & $-1,8759$ \\
\hline Myristicaceae & Virola bicuhyba & $1,875,185$ & $1,826,445$ & 2,5992 & $1,887,385$ & $-0,6506$ \\
\hline Myrsinaceae & Myrsine coriacea & $1,250,465$ & 827,255 & 33,8442 & 973,245 & 22,1694 \\
\hline \multirow[t]{6}{*}{ Myrtaceae } & Calyptranthes grandifolia & 653,325 & 385,815 & 40,9459 & 307,050 & 53,0020 \\
\hline & Eugenia cerasiflora & 763,635 & 710965 & 6,8974 & 763,110 & 0,0687 \\
\hline & Eugenia oblongata & 776,135 & 395595 & 49,0301 & 342,085 & 55,9245 \\
\hline & Marlierea obscura & 936,205 & 505290 & 46,0278 & 464,920 & 50,3399 \\
\hline & Marlierea tomentosa & 827,375 & 505340 & 38,9225 & 445,185 & 46,1931 \\
\hline & Myrcia pubipetala & 812,445 & 400505 & 50,7037 & 338,450 & 58,3418 \\
\hline Nyctaginaceae & Guapira opposita & 813,670 & 565990 & 30,4399 & 584,670 & 28,1441 \\
\hline Olacaceae & Heisteria silvianii & 232,200 & 338285 & $-45,6869$ & 197,400 & 14,9871 \\
\hline Phyllanthaceae & Hyeronima alchorneoides & $1,209,780$ & 480610 & 60,2729 & 356,830 & 70,5046 \\
\hline Rubiaceae & Amaioua guianensis & $1,606,795$ & 1712730 & $-6,5929$ & $1,737,790$ & $-8,1526$ \\
\hline Sapindaceae & Cupania oblongifolia & 467,430 & 449850 & 3,7610 & 379,630 & 18,7836 \\
\hline \multirow[t]{2}{*}{ Sapotaceae } & Chrysophyllum flexuosum & 526,580 & 418545 & 20,5164 & 336,340 & 36,1275 \\
\hline & Ecclinusa ramiflorat. & 881,920 & 664095 & 24,6990 & 704,605 & 20,1056 \\
\hline Vochysiaceae & Vochysia magnifica & 348,965 & 270500 & 22,4851 & 179,175 & 48,6553 \\
\hline
\end{tabular}

São Paulo State; the South-eastern region and the Zona da Mata of Minas Gerais State; the Central part of Rio de Janeiro State, and finally, the Central mesoregion of Espírito Santo State (Figure 6).

But if we consider the maps of potential distribution of the species in the future, these areas of concomitant occurrence of those 38 species are reduced to the Northwest of Rio Grande do Sul State; the West of Santa
Catarina State; the Serra do Mar and coastal areas from Paraná, São Paulo and Rio de Janeiro states; some areas of Minas Gerais and Espírito Santo states. Extremely important areas included in these projections are the Cantareira-Japi region and areas along the Paraíba River valley in São Paulo State.

The shift towards more southern and cooler areas has also been observed for the Cerrado trees (Siqueira and 
Peterson, 2003), as well as for Lutzomyia sand flies, that are cutaneous leishmaniasis vectors in South America, Peterson and Shaw (2003).

Some authors (Thompson and Mead, 1982; Wells, 1983; Lyons, 2003) exemplify in their works the movement of some species to warmer climates. This preferential direction for an ecological niche that is more appropriate for survival, which happened 18,000 years ago during the last glaciation, shows that the species may dislocate as a response to climatic changes. Using the same techniques of modelling used in the present work, Martínez-Meyer et al. (2004) showed that the movement of species to warmer or cooler places, according to their characteristics, is possible when climate change speed is compatible with the evolutive process. In this case, migrations may result in speciation and or occupation of new habitats. The speed of the changes in climate (IPCC, 2007) and the high fragmentation of Brazilian biomes such as the Cerrado (Cavalcanti and Joly, 2002) and the Atlantic Forest (Fonseca, 1989; Laurance and Delamonica, 1998) make unviable the natural process of expansion and retraction as those registered millions of years ago.

Such changes in the areas of potential occupation are intrinsically affected by biological aspects, not contemplated in this work. Ecological interactions with other species, such as dispersion, pollination, symbiosis and parasitism were not considered, because to minimise distortions, it would be necessary to model the consequences of global warming individually for each one of the species involved in these interactions.

Another extremely important limitation is the resolution of the maps and climate models used. Due to the inexistence of detailed meteorological information about South American countries, including Brazil (Sentelhas et al., 2000), the quality of the predictions is limited by the resolution of the generic world climate models. In areas of huge variations of altitudes in short-distances as in the Serra do Mar, there are problems with the accuracy of the climate information used, because in the $50 \times 50 \mathrm{~km}$ grid these topographic details are lost. And as shown by Salis et al. (1995), some species of Atlantic Forest trees are already limited to cooler areas.

In the past, significant areas of Atlantic Forest were preserved where the topography was too steep for the extensive agriculture such as the Serra do Mar, from Espirito Santo to Santa Catarina States, and the Serra da Mantiqueira, between São Paulo, Minas Gerais and Rio de Janeiro States. However, the expansion of the big cities, mainly capitals and metropolitan regions of southeast and southern regions, the construction of large touristic resorts for vacation and weekends, the expansion of shantytowns, of roads, of water dams, and of electricity transmission lines, have destroyed most of the original biodiversity of the Atlantic Forest.
Now, in the same way as happened with the air pollution of a major chemical-petrochemical and fertilizer industrial area in Cubatão (Klockow et al., 1997; Klump et al., 2002), which has eliminated a large number of species of plants and animals in a part of the Serra do Mar known as Serra de Paranapiacaba, it is not physical occupation but the atmospheric changes that is the new threat to this natural heritage.

Acknowledgements - We would like to thank the team at CRIA for all the fruitful discussions and suggestions, as well as for the technical support for developing and testing the models. We are also grateful to Dr. Fernando Roberto Martins, from the Botany Department at IB/UNICAMP, for the use of his databank on Atlantic Forest species, as well as for helping us to select the target species used. This research was partially supported by the State of São Paulo Research Foundation (FAPESP) as part of the Thematic Project Functional Gradient (Process Number 03/12595-7), within the BIOTA/FAPESP Programme - The Biodiversity Virtual Institute (http://www.biota.org.br). COTEC/ IF 41.065/2005 and IBAMA/CGEN 093/2005.permits.

\section{References}

ALMEIDA, FFM. and CARNEIRO, CDR., 1998. Origem e evolução da Serra do Mar. Revista Brasileira de Geociências, vol. 28 , no. 2 , p. $135-150$.

BEHLING, H. and NEGRELLE, RRB., 2001. Late Quaternary tropical rain forest and climate dynamics from the Atlantic lowland in southern Brazil. Quaternary Research, vol. 56, p. 87-101.

BROW Jr., KS., 1987. Conclusion, synthesis and alternative hypotheses. In WHITMORE, TC. and PRANCE, GT. (Eds.). Biogeography and Quartenary history in Tropical America. p. 175-196. Oxford Science Publications.

BUSH, MB. and OLIVEIRA, PE., 2006. The rise and fall of the Refugial Hypothesis of Amazonian speciation: a paleoecological perspective. Biota Neotropica, vol. 6, no. 1. Available from: $<$ http://www.biotaneotropica.org.br/v6n1/en/abstract?point-ofview+bn00106012006>.

CAVALCANTI, RB. and JOLY, CA., 2002. Biodiversity and Conservation Priorities in the Cerrado Region. In OLIVEIRA, PE. and MARQUIS, RJ. (Eds.). The Cerrados of Brazil. Ecology and Natural History of a Neotropical Savana. New York: Columbia Univesity Press, p. 351-367.

CHAPMAN, AD., MUÑOZ, MES. and KOCH, I., 2005. Environmental information: placing biodiversity phenomena in an ecological and environmental context. Biodiversity Informatics, vol. 2, p. 24-41.

COSTA, LP., 2003. The historical bridge between the Amazon and the Atlantic Forest of Brazil: a study of molecular phylogeography with small mammals. Journal of. Biogeography, vol. 30, no. 1, p. 71-86.

ELITH, J., GRAHAM, CH. and ANDERSON, RP., 2006. Novel methods improve prediction of species' distributions from occurrence data. Ecography, vol. 29, p. 129-151.

FONSECA, GAB., 1989. Small mammal species diversity in Brazilian tropical primary and secondary forests of different sizes. Revista Brasileira de Zoologia, vol. 6, no. 3, p. 381-422. 
Fundação S.O.S. Mata Atlântica and Instituto Nacional de Pesquisas Espaciais - INPE, 1998. Atlas da evolução dos remanescentes florestais e ecossistemas associados no domínio da Mata Atlântica no período 1990-1995. São Paulo.

Instituto Brasileiro de Geografia e Estatística - IBGE, 1988. Mapa de Vegetação do Brasil. Brasília, DF: IBGE.

Instituto Brasileiro de Geografia e Estatística - IBGE, 1993. Mapa de vegetação do Brasil. Rio de Janeiro, IBGE. Available from: <http://mapas.sosma.org.br/>.

International Panel on Climate Change - IPCC, 2007. Climate change 2007: Mitigation - Contribution of Working group III to the Fourth Assessment Report of the Intergovernmental Panel on Climate Change. Cambridge: Cambridge University Press.

JOLY, CA., AIDAR, MPM. and KLINK, CA., 1999. Evolution of the Brazilian phytogeography classification systems: implications for biodiversity conservation. Ciência e Cultura, vol. 51, no. 5/6, p. 331-348

KLOCKOW, D., TARGA, HJ. and VAUTZ, W., 1997. Air pollution and vegetation damage in the tropics - the Serra do Mar as an example. Geesthacht, Germany: GKSS -Forschungszentrum Geesthacht. Final Report 1990-1996.

KLUMP, A., DOMINGOS, M. and KLUMP, G., 2002. Foliar nutrient contents in tree species of the Atlantic Rain Forest as influenced by air pollution from the industrial complex of Cubatão, SE-Brazil. Water, Air, Soil Pollution, vol. 133, p. 315-333.

LAURANCE, WF. and DELAMONICA, P., 1998. Ilhas de sobrevivência. Ciência Hoje, vol. 24, p. 26-31.

LEDRU, MP., ROUSSEAU, DD., CRUZ Jr., FW., RICCOMINI, C., KARMANN, I. and MARTIN, L., 2005. Paleoclimate changes during the last $100 \mathrm{ka}$ from a record in the Brazilian Atlantic rainforest region and interhemispheric comparison. Quaternary Research, vol. 64, p. 444-450.

LYONS, KS., 2003. A quantitative assessment of the rate of range shifts of Pleistocene mammals. Journal of Mammalogy, vol. 84 , p. 385-402.

MARTINEZ-MEYER, E., PETERSON, AT. and HARGROVE, WW., 2004. Ecological niches as stable distributional constraints for Pleistocene extinctions and climate change projections for biodiversity. Global Ecology and Biogeography, vol. 13, p. 305-314.

MYERS, N., MITTERMEIER, RA., MITTERMEIER, CG., FONSECA, GAB. and KENT, J., 2000. Biodiversity hotspots for conservation priorities. Nature, vol. 403, p. 853-858.

OLIVEIRA FILHO, AT. and FONTES, MAL., 2000. Patterns of floristic differentiation among Atlantic forests in Southeastern Brazil, and the influence of climate. Biotropica, vol. 32, no. 4b, p. $793-810$.

OLIVEIRA, RJ., 2001. Análise da variação florístico-estrutural das florestas atlânticas no estado de São Paulo, Brasil. Campinas: Biology Institute State University of Campinas. [PhD Thesis].

PETERSON, AT. and SHAW, J., 2003. Lutzomyia vectors for cutaneous leishmaniasis in Southern Brazil: ecological niche models, predicted geographic distributions, and climate change effects. International Journal for Parasitology, vol. 33, p. 919-931.
PETERSON, AT., 2001. Predicting species' geographic distributions based on ecological niche modeling. The Condor, vol. 103, p. $599-605$.

PETERSON, AT., BALL, LG. and COHOON, KC., 2002. Predicting distributions of Mexican birds using ecological niche modeling methods. Ibis, vol. 144, p. 27-32.

PETERSON, AT., PAPES, M. and EATON, MUIR., 2007. Transferability and model evaluation in ecological niche modeling: a comparison of GARP and Maxent. Ecography, vol. 30, no. 4, p. $550-560$.

PETERSON, AT., SOBERON, J. and SANCHEZ-CORDERO, V., 1999. Conservatism of ecological niches in evolutionary time. Science, vol. 285, no. 1265-1267.

PHILLIPS, SJ., ANDERSON, RP. and SCHAPIRE, RE., 2006. Maximum entropy modeling of species geographic distributions. Ecological Modelling, vol. 190, no. 231-259.

RIBEIRO, MC., METZGER, JP., MARTENSEN, AC., PONZONI, FJ. and HIROTA, MM., 2009. The Brazilian Atlantic Forest: How much is left, and how is the remaining forest distributed? Implications for conservation. Biological Conservation, vol. 142, p. 1141-1153.

RIZZINI, CT., 1997. Tratado de fitogeografia do Brasil. 2 ed. Ambito Cultural Edições Ltda.

ROCHELLE, ALC., 2008. Heterogeneidade ambiental, diversidade e estrutura da comunidade arbórea de um trecho da Floresta Ombrófila. Campinas: Biology Institute, State University of Campinas. [MSc Thesis].

RODRIGUES, RR., MARTINS, SV. and GANDOLFI, S., 2007. High Diversity Forest Restoration in Degraded Areas: Methods and Projects in Brazil. Hauppauge, New York: Nova Science Publishers.

SALIS, SM., SHEPHERD, GJ. and JOLY, CA., 1995. Floristic comparison between mesophytic forests of the interior of the state of São Paulo, S.E. Brazil. Vegetatio, vol. 119, p. 155-164.

SCUDELLER, VV. and MARTINS, FR., 2003. FITOGEO um banco de dados aplicado à Fitogeografia. Acta Amazônica, vol. 33 , no. 1, p. 9-21.

SENTELHAS, PC., PEREIRA, AR. and ANGELOCCI, LR., 2000. Meteorologia Agrícola. 3 ed. Piracicaba, SP: ESALQ.

SinBiota, 2006. Sistema de informação ambiental do programa. BIOTA/FAPESP. Available from: <http://sinbiota.cria.org.br/>.

SIQUEIRA, MF. and PETERSON, AT., 2003. Consequences of global climate change for geographic distributions of Cerrado tree species. Biota Neotropica, vol. 3, no. 2. Available from: $<$ http://www.biotaneotropica.org.br/v3n2/pt/fullpaper?bn0080302 $2003+$ en $>$.

SpeciesLink, 2006. Sistema de Informação Distribuído para Coleções Biológicas: a Integração do Species Analyst e do SinBiota. Available from: <http://splink.cria.org.br/>.

STOCKWELL, DRB. and NOBLE, I., 1992. Induction of sets of rules from animal distribution data: a robust and informative method of data analysis. Mathematics and Computer in Simulation, vol. 33, p. 385-390.

STOCKWELL, DRB. and PETERS, DP., 1999. The GARP modeling system: problems and solutions to automated spatial 
prediction. International Journal of Geographic Information Science, vol. 13, p. 143-158.

THOMAS, WMW., CARVALHO, AMV., AMORIM, AMA., GARRISON, J. and ARBELÁZ, AL., 1998. Plant endemism in two forests in southern Bahia, Brazil. Biodiversity and Conservation, vol. 7, p. 311-322.

THOMAZ, LD. and MONTEIRO, R., 1997. Composição florística da Mata Atlântica de encosta da Estação Biológica de Santa Lúcia, município de Santa Teresa-ES. Boletim do Museu de Biologia Mello-Leitão, Nova Série, vol. 7, p. 3-48.

THOMPSON, RS. and MEAD, JI., 1982. Late Quaternary environments and biogeography in the Great Basin. Quaternary Research, vol. 17, p. 39-55.

WELLS, PV., 1983. Paleobiogeography of montane islands in the Great Basin since the last glaciopluvial. Ecological Monographs, vol. 53, p. 341-382. 